\title{
10: 115793796-115795518
}

National Cancer Institute

\section{Source}

National Cancer Institute. 10:115793796-115795518. NCI Thesaurus. Code C41662.

Physical location of ADRB1_Gene 